\title{
PALAEOSEISMOLOGICAL ANALYSIS OF THE EAST GIOUCHTAS FAULT, HERAKLION BASIN, CRETE (PRELIMENARY RESULTS)
}

\author{
Zygouri V. ${ }^{1}$, Koukouvelas I. ${ }^{1}$, and Ganas A. ${ }^{2}$ \\ ${ }^{1}$ University of Patras, Department of Geology, 26500, Rion Patras, Greece, zygouri@upatras.gr, \\ iannis@upatras.gr \\ ${ }^{2}$ Institute of Geodynamics, National Observatory of Athens, 11810 Athens, Greece, \\ aganas@noa.gr
}

\begin{abstract}
A paleoseismological analysis has been performed at the East Giouchtas Fault. This fault dips to the east and represents a pure normal fault. The East Giouchtas Fault forms an intrabasinal high in the Heraklion basin with its conjugate fault the West Giouchtas Fault. A natural surface has been prepared and logged in detail in order to detect the most significant parameters related to the ground shaking impact on the area. Investigating past earthquakes characteristics attributed to the East Giouchtas Fault and through sample dating we conclude that the studied fault is related to at least four strong events of 6.4 magnitude. The fault is also characterized by 20-40 cm tectonosedimentatry displacements and slip rates of $0.25 \mathrm{~mm} / \mathrm{yr}$. Thus, the proximity of the fault to the highly populated Heraklion city and Minoan Knossos monument urges the need for an adequate hazard assessment of the area.
\end{abstract}

Keywords: active tectonics, seismic hazard, young surface scarp, seismic history.

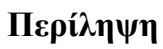

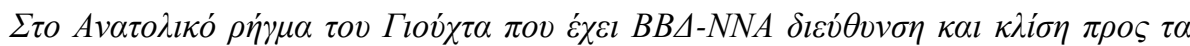

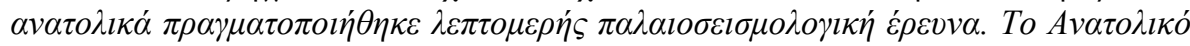

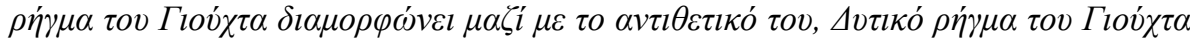

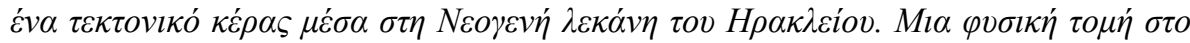

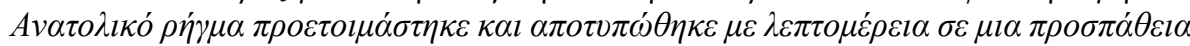

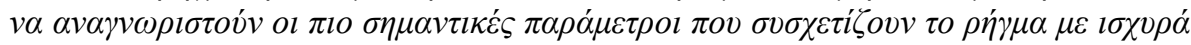

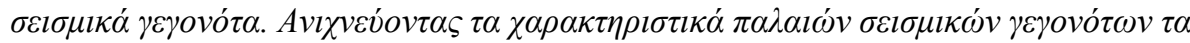

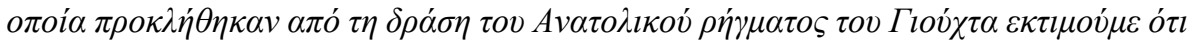

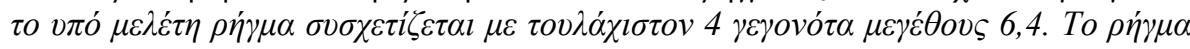

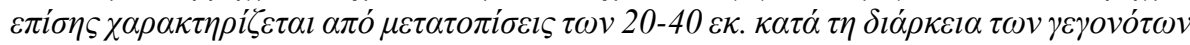

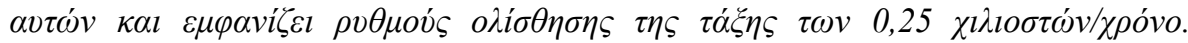

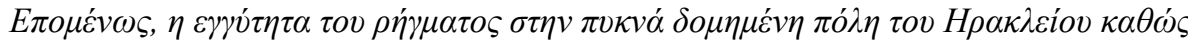

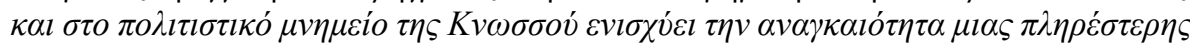

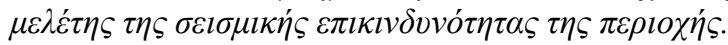

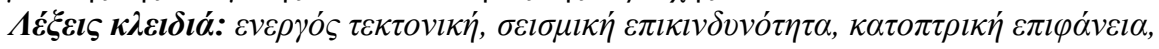

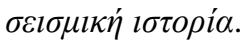




\section{Introduction}

Paleoseismological analysis through trenching investigations of fault related colluvial tectonostratigraphy can facilitate the improvement of historical seismological data and thus can be a valuable tool that can provide data regarding the occurrence of destructive prehistoric earthquakes (McCalpin, 1996; Pavlides et al., 1999). Paleoseismology includes the study of the location, timing and size of prehistoric earthquakes and attempts to interpret geological evidence attributed to individual paleoearthquakes (Solonenko, 1973; Sieh, 1978; Wallace, 1981; McCalpin, 1996). Paleoseismology uses both geomorphological and geological evidence of past seismic shaking and/or ground rupture to prolong the timing of applied earthquake studies. It differs from general active tectonic studies as it is focused on the almost instantaneous deformation of landforms and sediments during earthquakes (Allen, 1986). In the past decades data collected in several detailed paleoseismic studies have been used to develop remarkable new concepts about the earthquake generation process. Recently there has been an increasing interest also in Greece in defining specific seismic events with the use of trenching excavation despite the fact that historical records show notable qualitative data (Pavlides et al,. 2004; Chatzipetros and Pavlides, 1994; Collier et al., 1998; Pantosti et al., 2004; Koukouvelas et al., 2005; Kokkalas et al., 2007; Zygouri et al., 2015).

This study is contributing to seismic hazard assessment and understanding of earthquake history of the Heraklion area. Note that in the Heraklion area, seismic energy release is significant (Papadopoulos, 2011) and this conclusion strengthen our effort to study some of these past earthquakes through paleoseismology. The present study provides information on the seismic history of the East Giouchtas fault by means of trenching techniques, tectonostratigraphy of fault colluvial sequences and radiocarbon dating. Whether or not this fault has the potential of hosting surface rupturing earthquake events was not previously known or estimated. Knowledge of timing, location and slip distribution of past earthquakes is critical to understand the long - term behavior of this fault and to attempt to forecast future large earthquakes that can have great impact on the epicentral area.

\section{Geological setting}

The island of Crete is located in the southernmost part of the Hellenic arc (Fig. 1a) on the Aegean plate that overrides the lower Nubian plate (Ganas and Parsons, 2009). It constitutes one of the most seismically active areas of the Eastern Mediterranean which is associated with high rates of tectonic uplift ( $>6 \mathrm{~mm} / \mathrm{yr}$ ) and dissected by a dense array of primarily normal faults. These faults have length up to $10 \mathrm{~km}$ and they are associated possibly with strong earthquakes of magnitude 6 . They juxtapose Mesozoic carbonates and alpine metamorphic rocks from coarse-grained alluvium and colluviums sediments (Doutsos and Kokkalas, 2001; Fassoulas, 2001; Kokinou et al., 2015). The Heraklion basin, characterized by a rather tabular onshore pattern, represents a Neogene fault bounded basin. Particularly, the basin to the east is bounded by the Kastelli normal fault and to the west by the Kroussonas-Tylissos normal fault (Doutsos and Kokkalas, 2001; Vassilakis, 2006; Fig. 1b). To the south the Heraklion basin is bounded by an E-W mountainous range that borders the northern end of the Messara Basin. Giouchtas Mt located in the central part of the basin forms an intrabasinal high or a horst, called hereinafter as Giouchtas horst, controlled by two well-exposed boundary faults, i.e. the East and West Giouchtas Faults (Fig. 1c). Both of those faults are trending NNW-SSE and their mapped length is 6 and $8 \mathrm{~km}$ respectively. The case of the Giouchtas horst appears as most appealing due to mainly two reasons. It is located near the Heraklion city, it exposes fresh scarp surfaces (Fig. 1d) which juxtapose for more than $400 \mathrm{~m}$ Triassic limestones against flysch, marls and unconsolidated alluvial to colluvial sediments.

\section{Paleoseismology}

We used trenching method to reconstruct the latest Quaternary paleoseismic history of East Giouchtas Fault and to examine its rupture behavior. Among the various indicators for 
paleoseismology in unconsolidated sediments within a normal fault setting, the best and clearest indicators for faulting are fault scarps, scarp derived colluviums, upward termination of faults offset sedimentary layers and landslides/liquefactions (McCalpin, 2009).

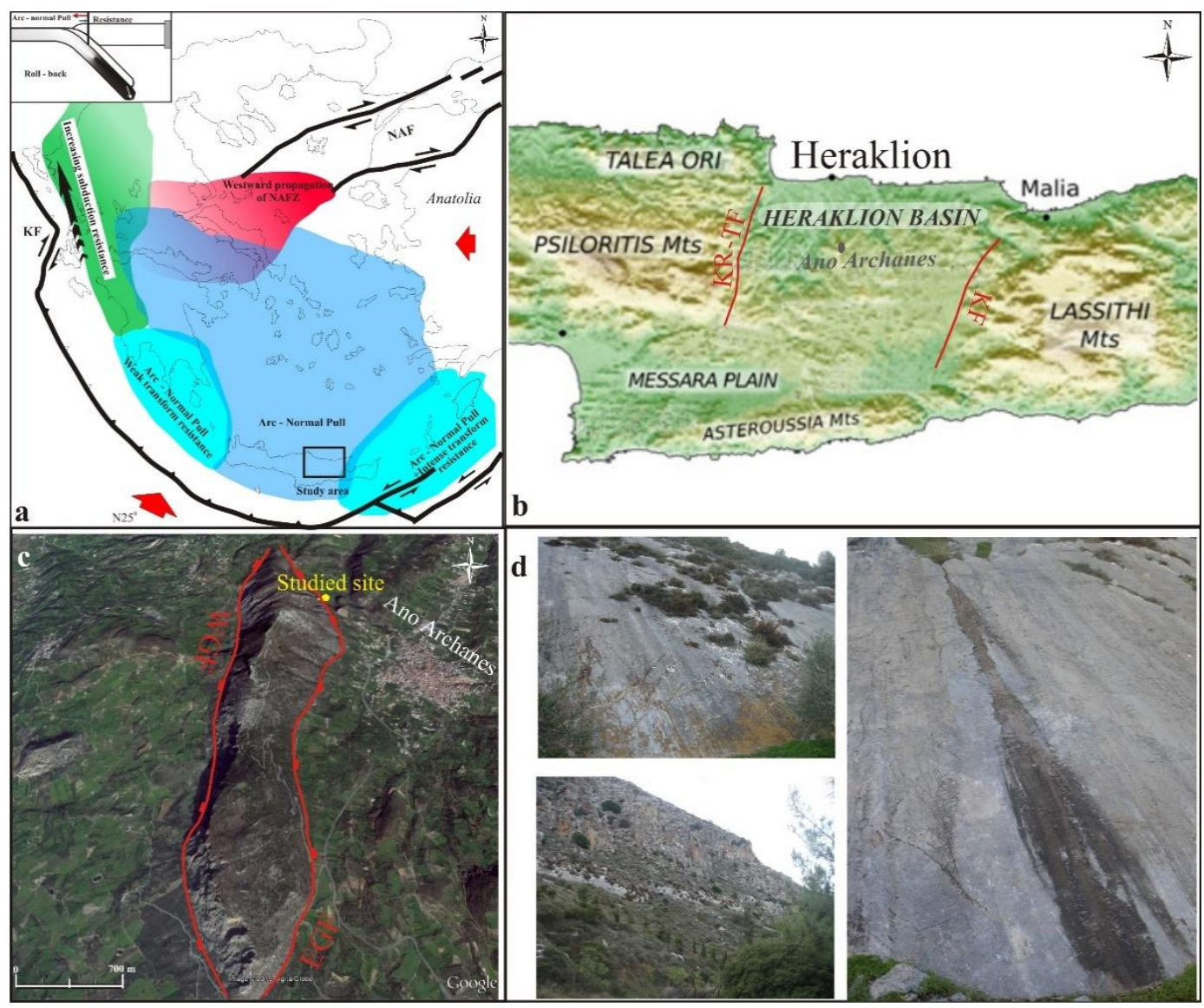

Figure 1 - a) The geodynamic setting of the Hellenic peninsula affecting the study area (modified by Kokkalas et al., 2006), b) The Herakion basin bounded by the Kroussonas -

Tylissos fault (KR-TF) and Kastelli fault (KF) modified by (Vassilakis, 2006), c) The

Giouchtas intrabasinal high formed by the West and East Giouchtas faults. The yellow point marks the paleoseismological site, $d$ ) Photos from the study area showing active features of the East Giouchtas Fault taken on Aug. 17, 2014.

In this study, we focus our efforts on the East Giouchtas Fault at a site where a landslide activated during the road construction connecting Ano Archanes with Vasilies hamlet. Based on Google Map archive the landslide is forested since 2006. Thus, it is suggested that the slide is stable at present. The slide was developed perpendicular to the East Giouchtas Fault trace and landslide minor scarp represents an east- west surface being at an ideal orientation to be used as a palaeoseismological trench with an excess of new information, exposing paleosoils and displaced colluviums (Fig. 2a). This practice was selected in the present study due to strong archaeological restrictions that forbidden the use of mechanical means to excavate a paleoseismological trench a restriction expanded also to the cleaning and configuring of the landslide minor scarp. So, we performed the outcrop's cleaning by hand.

Regarding the parameters of the landslide, its crown is located at about $5 \mathrm{~m}$ below the active fault scarp (Fig. 2b). At this particular site the east facing fault scarp has a dip of $55^{\circ}$ and is almost $4 \mathrm{~m}$ tall. The section we analyzed has a length of $40 \mathrm{~m}$ and its maximum height is $4.5 \mathrm{~m}$. Photo mosaics 
of the trench were developed using image processing software. The ages of stratigraphic units that are displaced or the deposits derived just after a seismic event, such as colluvial deposits, were used to constrain past earthquakes and estimate recurrence interval (McCalpin, 2009 and references therein). We collected all available radiocarbon samples in the trench and selected six of them as the most promising for dating the stratigraphic horizons and the colluvial wedges exposed in the trench. AMS radiometric analyses were performed by Beta Analytic, Florida, USA. Our dating results are presented in Table 1 except the GI6 sample that was unable to be dated by the laboratory.

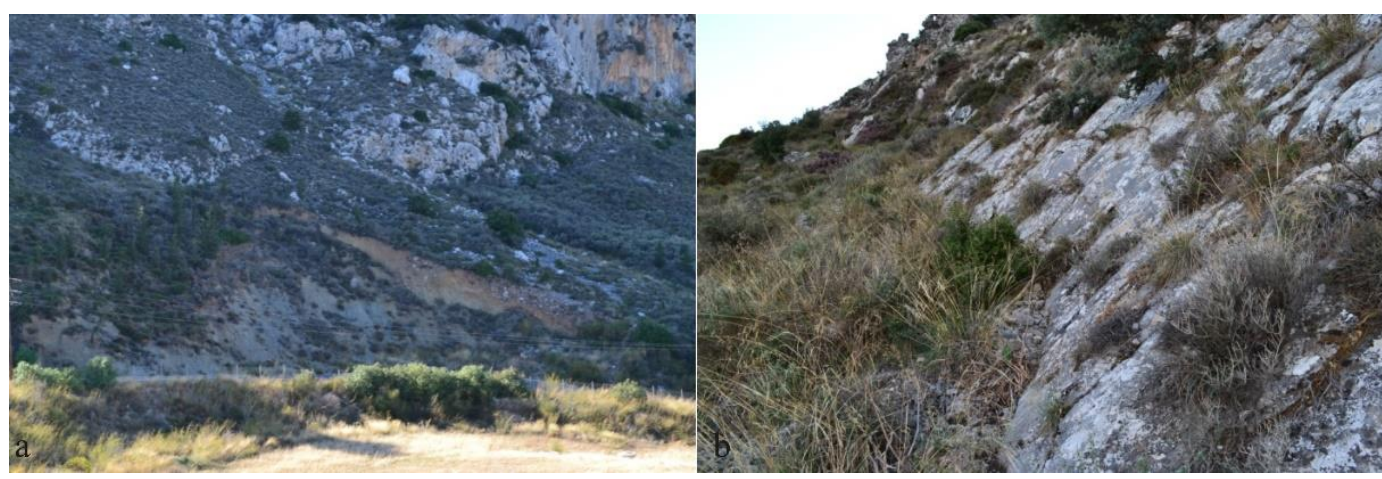

Figure 2 - a) View of the landslide lying underneath the fault scarp of East Giouchtas fault, b) Fault scarp above the landslide site with $55^{\circ}$ dip (both photos were taken on Oct. 24, 2014).

\subsection{Description of the paleoseismological trench}

The trench exposed coarse and medium grained sediments overlying flysch (Fig. 3). It also revealed a succession of unconsolidated sandy horizons, apparently displaced paleosoils and colluvial deposits rich in organic material. The unconsolidated sediments are displaced by four faults, being considered based on their dip as synthetic to the main East Giouchtas Fault. The upper part of the flysch which is in contact with the unconsolidated sediments is slightly weathered and comprises a transitional clay horizon to the flysch (unit CF). Furthermore, the trench tectonostratigraphy is divided in two parts: the west, called hereinafter as succession A, and the east, called succession B, both of which are controlled by F1-F3 faults. In particular the west part of the tectonostratigraphy is located between F1-F2 faults being strongly attenuated towards both faults and partly interfingering with the succession $\mathrm{B}$. In addition this part is displaced by the F1 fault suggesting the syntectonic evolution of the succession A. In detail the succession A includes from bottom to the top the following units: one 20-40 cm thick yellow sandy unit with sparse limestone boulders (unit Sep) that is displaced by both F1 and F2 faults. This unit, overlying the flysch is a red- yellow colored of fine grained sediments including sparse angular to subangular clasts. On top of Sep unit a 10-cmthick red paleosoil horizon (P) is recognized. F1 fault displaces the paleosoil horizon (P) by almost $40 \mathrm{~cm}$ (Fig. 3). On top of Sep unit or the paleosoil a green color shade unit with abundant angular limestone clasts in a sandy matrix is developed (unit $\mathrm{Gr}$ ). Unit $\mathrm{Gr}$ is strongly attenuated towards fault F2 and is displaced by F1 fault. On top of unit $\mathrm{Gr}$ a red colored unit (Rd) with abundant rounded clasts or boulders of limestone is developed, including also in cases conglomerate lenses with a clay matrix. Unit Rd appears to be displaced by F1 and F2 faults. Both the (Gr) and the (Rd) units have been displaced by $\mathrm{F} 1$ fault by about $30 \mathrm{~cm}$. Of particular interest for the understanding of the trench is the existence of a boulder cluster across the F1 fault trace suggesting probably that the slip of the fault is associated with a graben formed parallel to the fault, wide enough to capture the CeCong unit. On top of the unit Rd and on the hangingwall of F1 fault CW2 colluvial wedge is developed. 


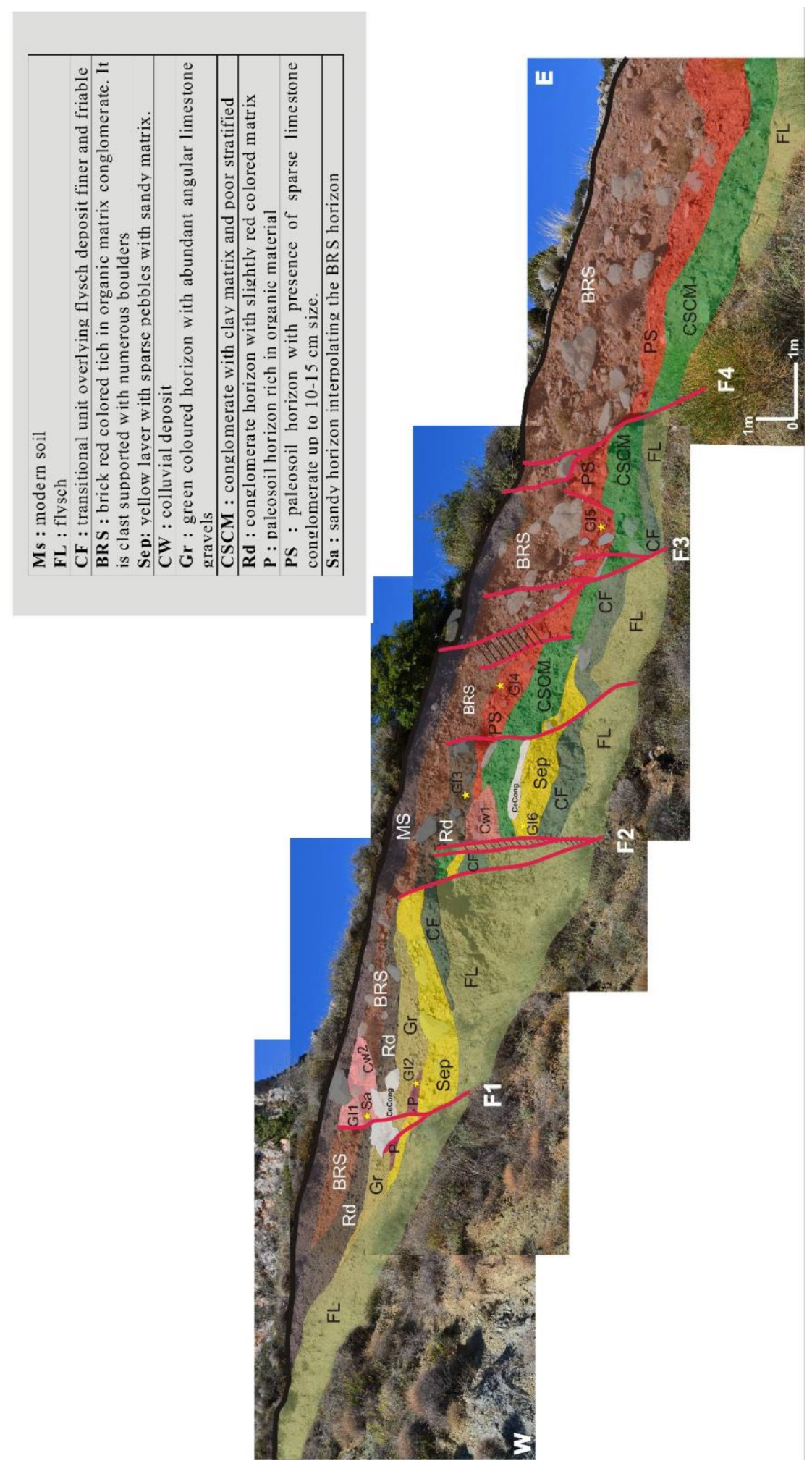

Figure 3 - Photomosaic and sketching of the section stratigraphy (photos taken on Oct. 25, 2014). View towards North. 
This wedge includes unsorted angular cobbles and boulders in a sandy matrix rich in organic material (Sa, in Fig. 3). The rest of Rd unit is overlain by BRS unit. BRS unit is characterized as a brick red color conglomerate unit rich in organic sand matrix or in cases by lenses of clast supported conglomerates. This unit is the only one that is exposed through the entire trench. However, it is important to note that this unit is progressively increasing its thickness eastward. This can be interpreted as a basinward sedimentation increase.

Succession B varies from succession A in two main points. Its age and the presence of two units that are not recognized on the footwall of F1. Most of this succession is developed over the last $6000 \mathrm{yrs}$ and is apparently maintaining an almost constant total thickness. However, its upper units increase in thickness, suggesting that during the last 5.500 yrs the sedimentation is shifted basinwards. Units CSCM and PS appear to be controlled by F2 and F3 faults. In summary, succession B includes the following units: The unit $\mathrm{CF}$ represents a moderate to well stratified clay horizon developed on top of the flysch deposits. On top of the unit CF, Sep unit is developed. Above Sep unit, a previously unrecognized unit is developed (unit CSCM). It is represented by a poorly stratified conglomerate with clay matrix. Colluvial wedge $\mathrm{Cw} 1$ is apparently related to F2 fault. Colluvial wedge $\mathrm{Cw} 1$ is characterized by poorly shorted and unstratified pebbles in a sand matrix. The colluvial deposit on F2 fault has $0.4 \mathrm{~m}$ thickness (Fig. 3). The detected bottoms of the colluvium, due to its darker color and clayey texture can be characterized as event horizon (unit CSCM). On top of the colluvial wedge Cw1 units Rd and PS are developed and they are either displaced (Rd unit) or attenuated (PS unit) against F2 fault. PS unit comprises a dark red-brown conglomerate unit rich in organic material matrix. The color of unit PS is red orange with sparse pebbles or lenses of conglomerates and sandy matrix rich in organic material. Furthermore, unit PS is well developed towards the east of the trench, maintaining an almost stable thickness and thus can be characterized as an event horizon. Based on this stratigraphy, it is assumed that unit PS predates the basinwards shift of the tectonic activity and the activation of F3 and F4 faults. On top of PS unit, the red brown conglomerate BRS unit is developed, showing a moderately well-developed stratification, being the only common horizon all the way through the trench. The bottom of BRS unit is erosive and its structure varies from matrix to clast supported. In places, i.e. in the downthrown block of F3 fault, it includes poorly shorted boulders in an organic rich sandy to silty matrix. Of particular interest is that the BRS unit is displaced by F1, F3 and F4 faults. The uppermost unit exposed on top of both sedimentary successions is the modern soil (MS). Close to F3 fault, MS unit seems displaced and attenuated or even extinct near F4 fault. This configuration is interpreted to be correlated with the most recent earthquake event in the area or with the landslide. F2 and F3 faults are characterized by a cataclasite zone of small thickness (less than $20 \mathrm{~cm}$ ) and by the deposition of colluvial deposits.

\subsection{Dating and interpretation of the events within the paleoseismological trench}

During the trench sketching and photography we collected six samples for AMS dating. Our sampling focused on the most significant sedimentary changes and is constrained by F1 and F4 faults. The samples were calibrated in years before present (Table 1). Overall, the ages derived by the dating procedure are also confirmed by the historical testimony. After considering the full distribution of ${ }^{14} \mathrm{C}$ ages and taking into account the stratigraphy of the trench, we interpreted four events (Fig. 4a). The most recent event is bracketed by sample GI1, dated at 2970-2850 BP. and the present day. The penultimate event within the trench is bracketed by GI3 and GI1 samples. It is related with the deposition of CeCong unit near F1 fault and the offset of PS unit across F3 fault. The second event is bracketed by GI3 and GI2 samples and offset the paleosoil horizon P across F1 fault and the part of succession B underlying Rd unit across the F2 fault (Fig. 4a).

The oldest event appears to be correlated with the colluvial deposit $\mathrm{Cw} 1$. The age of this event is older than the age of samples GI2 and GI5, yielding ages older than 5830 \pm 30 BP. This event is attributed to the F2 fault. The older limit of this event is not known (Fig. 4b). A thickness of almost $40 \mathrm{~cm}$ is preserved from the associated colluvial deposit. Based on the colluvial deposit's thickness, an event in the order of Mw 6.4 can be calculated according to the empirical formula proposed by 
Pavlides and Caputo (2004). However in order to evaluate possible magnitudes from this empirical formulas it is important to locate the trench in respect to the maximum displacement across the fault. Although the L-D distribution analysis of the fault is not published in detail, our trench is located close to the maximum height of the Giouchtas mountain (see Fig. 1c). So it is fair to say that our trench is near by the maximum displacement across the fault. Similar displacements are recognized also from all the events within the trench. According to the estimated amounts of displacement and their possible ages we can estimate $0.25-0.5 \mathrm{~mm} / \mathrm{yr}$ slip rate. It is noteworthy that similar values can be estimated by the exposed fault scarps being of almost $6-8 \mathrm{~m}$ high since the last glacial period (12000-18000 yrs, see also Caputo et al., 2006).

Table 1 - Dates of radiocarbon samples derived from East Giouchtas Fault.

\begin{tabular}{|c|c|c|c|c|c|}
\hline $\begin{array}{c}\text { Sample } \\
\text { No }\end{array}$ & $\begin{array}{c}\text { Laboratory } \\
\text { No }\end{array}$ & Description & ${ }^{13} \mathrm{C}$ & $\begin{array}{l}\text { Measured } \\
{ }^{14} \mathrm{C} \text { age }\end{array}$ & Calibrated age \\
\hline GI1 & 409937 & Organic sediment & $-25.6 \%$ & $2810 \pm 30 \mathrm{BP}$ & 2970-2850 B.P. \\
\hline GI2 & 409938 & Organic sediment & $-25.9 \%$ & $5880 \pm 30 \mathrm{BP}$ & 6770-6640 B.P. \\
\hline GI3 & 409939 & Organic sediment & $-25.1 \% 0$ & $4550 \pm 30 \mathrm{BP}$ & 5310-5060 B.P. \\
\hline GI4 & 409940 & Organic sediment & $-25.3 \% 0$ & $5480 \pm 30 \mathrm{BP}$ & 6307-6220 B.P. \\
\hline GI5 & 409941 & Organic sediment & $-25.4 \%$ & $5830 \pm 30 \mathrm{BP}$ & 6720-6560 B.P. \\
\hline
\end{tabular}
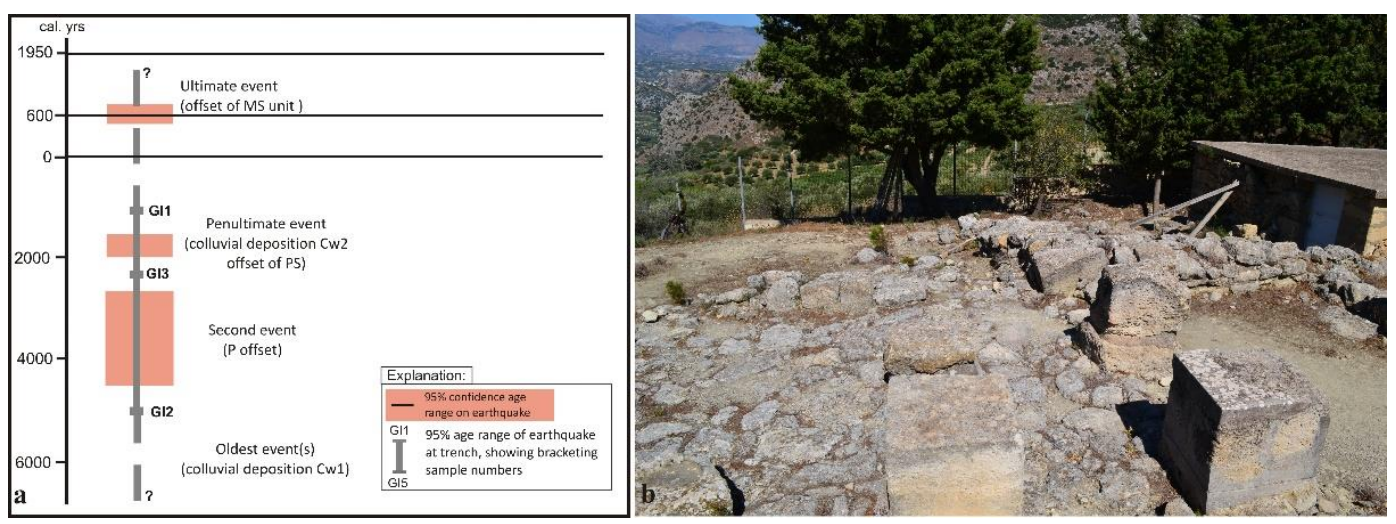

Figure 4 - a) ${ }^{14} \mathrm{C}$ dating results and estimated earthquake events in the East Giouchta Fault. b) Stone displacement, possibly by a strong ground shaking, in the archaeological site of the Giouchtas area that was prosperous during Minoan times.

\section{Discussion}

The historical earthquakes in the area of Crete have been extensively studied since one of the most tremendous events is located to the west of the island (365 A.D. event, Papadopoulos, 2011 and references therein). Vassilakis (2006) concluded that since Middle Miocene to the present Heraklion basin is undergoing an extension phase dominated by large scale active normal almost N-S trending faults. According to Caputo et al. (2006) the most significant active faults have the potential of producing 6.3 to 6.8 events, while the mean recurrence interval varies from 260 to 867 years. The possible magnitude calculated for the total exposed length of East Giouchtas Fault trace is 6.0, according to the empirical formula of Pavlides and Caputo (2004). However, the thickness of the colluvial deposits implies an event in the order of 6.4 magnitude. Taking into account this apparent discrepancy, we suggest that the actual fault length of the East Giouchtas Fault is possibly longer than its exposed trace length and its extension propagates towards the Knossos area and probably towards the Messara basin. This fault prolongation generates a sediment - sediment contact, thus co-seismic deformation is possibly much more diffused and difficult to be preserved (Caputo et al., 2004; Zygouri et al., 2015). In addition other faults in Crete, like the Ha Gorge segment (Caputo et al., 2006) also 
show anomalously high earthquake magnitudes not consistent with their length. The $8.5 \mathrm{~km}$ long Ha Gorge is the main segment in the $25 \mathrm{~km}$ long Ierapetra fault zone (Caputo et al., 2006). The case of Spili Fault trending ESE-WNW is also comparable to East Giouchtas Fault. It is characterized by steep young scarps, associated with four or five paleoearthquakes (Mouslopoulou et al., 2011). The Spili fault again can be considered as the main segment of a fault zone extending over than $20 \mathrm{~km}$.

The lengthy duration of the Minoan civilisation with many Palatian eras (Proto- Neo- etc.), detected from archaeological observations, attests to the high seismicity of Crete and especially for the Heraklion Basin, where the historical cities of Knossos and other archaeological sites, less glamorous, are located. From recent observations, two episodes of ground shaking impacts were identified between 4000 and 1700 B.C. in Knossos (Detorakis, 1990). Also a series of publications documented building collapse and extensive fire incident in the Minoan temple of Anemospilia during the $17^{\text {th }}$ century B.C. (Sakellarakis, 1994, 1997). Based on our dating these events are possibly related to ultimate and penultimate events. Moreover, the fact that Ms unit is displaced by F3 fault is possibly correlated with the ultimate event occuring sometime after the deposition of the unit Sa (Fig. 3) and the present time. One of the earthquakes of the Byzantine era, described by many Byzantine chronographers at around $6^{\text {th }}$ and $7^{\text {th }}$ century, might correspond to our paleoseismological described ultimate event.

\section{Conclusion}

Using trenching paleoseismological techniques conducted at a landslide site of the East Giouchtas Fault we obtained a reconstruction of the seismic background on the area. Our outcomes are summarized as follows:

- Structural data associated with paleoseismological studies allowed us to classify satisfactorily the East Giouchtas Fault as an active normal fault in close proximity to the modern city of Heraklion and the Knossos archaeological site.

- The East Giouchtas Fault hosted at least four past events and represents a potential hazard to Heraklion city.

- Chronological constraints of past events and estimated slip on the studied fault suggest surface rupture with a recurrence interval of 2000 years (paleoseismological and historical data) with a slip rate of $0.25-0.5 \mathrm{~mm} / \mathrm{yr}$.

- Although we are aware that the paleoseismological data are limited, we consider this study as a valuable contribution for further research of other faults located on the Heraklion basin as part of the seismic hazard assessment of the area.

\section{Acknowledgments}

This research was funded by GSRT (Greek Secretariat for Research and Technology) under the Act "Infrastructure Upgrade for Seismic Protection of the Country and Strengthen Service Action - "SHIELD ASPIDA" implemented under the Action "Development proposals for Research Bodies - KRIPIS". The authors would also like express their appreciation to G. Soundoulounakis for his help during fieldwork.

\section{References}

Allen, C.R., 1986. Seismological and paleoseismological techniques of research in active tectonics. In: Wallace, R.E., (Panel Chairman), ed., Active Tectonics, National Academy Press, Washington, 148-154.

Caputo, R., Helly, B., Pavlides, S. and Papadopoulos, G., 2004. Paleoseismological investigation of the Tyrnavos fault (Thessaly, Central Greece), Tectonophysics, 394, 1-20.

Caputo, R., Monaco, C. and Tortorici, L., 2006. Multiseismic cycle deformation rates from Holocene normal fault scarps on Crete (Greece), Terra Nova, 18, 181-190.

Chatzipetros, A. and Pavlides, S., 1994. Late Quaternary fault scarps and paleoseismology of the active basin of Mygdonia, Thessaloniki seismogenic area, Northern Greece. In: Proc. Workshop on Paleoseismology (Scwartz and Yeats, eds., CA. USA), 35-37. 
Collier, R.E.L., Pantosti, D., D'Addezio, G., De Martini, P.M., Masana, E. and Sakellariou, D., 1998. Paleoseismicity of the 1981 Corinth earthquake fault: seismic contribution to extensional strain in central Greece and implications for seismic hazard, J. Geophys. Res., 103, 30001-30019.

Detorakis, T., 1990. History of Crete. Heraklion, 550 (in Greek).

Doutsos, T. and Kokkalas, S., 2001. Stress and deformation patterns in the Aegean region, J. Struct. Geol., 23, 455-472.

Fassoulas, C., 2001. The tectonic development of a Neogene basin at the leading edge of the active European margin: The Heraklion basin, Crete, Greece, J. Geodyn., 31, 49-70.

Ganas, A. and Parsons, T., 2009. Three-dimensional model of Hellenic Arc deformation and origin of the Cretan uplift, J. Geophys. Res., 114, doi: 10.1029/2008JB005599.

Kokinou, E., Skilodimou, H.D., Bathrellos, G.D., Antonarakou, A. and Kamberis, E., 2015. Morphotectonic analysis, structural evolution/pattern of a contractional ridge: Giouchtas Mt., Central Crete, Greece, J. Earth Syst. Sci., 124, 587-602.

Kokkalas, S., Xypolias, P., Koukouvelas, I.K. and Doutsos, T., 2006. Post-Collisional Contractional and Extensional Deformation in the Aegean Region. In: Post-Collisional Tectonics and Magmatism in the Mediterranean region and Asia. In: Dilek, Y. and Pavlides, S., eds., Geol. Soc. Am. Special Paper, 409, 97-123.

Kokkalas, S., Pavlides, S., Koukouvelas, I., Ganas, A. and Stamatopoulos, L., 2007. Paleoseismicity of the Kaparelli fault (eastern Corinth Gulf): evidence for earthquake recurrence and fault behavior, Boll. Soc. Geol. It. (Ital. J. Geosci.), 126, 387-395.

Koukouvelas, I.K., Katsonopoulou, D., Soter, S. and Xypolias, P., 2005. Slip rates on the Helike Fault, Gulf of Corinth, Greece: new evidence from geoarchaeology, Terra Nova, 17, 158-164.

McCalpin, J.P., 1996. Paleoseismology. Academic Press, San Diego, CA p. 588.

McCalpin, J.P., 2009. Paleoseismology. Academic Press, San Diego, CA p. 613.

Mouslopoulou, V., Moraetis, D. and Fassoulas, C., 2011. Identifying past earthquakes on carbonate faults: Advances and limitations of the "Rare Earth Element" method based on analysis of the Spili Fault, Crete, Greece, Earth. Planet Sci. Lett., 309,45-55.

Pantosti, D., De Martini, P., Koukouvelas, I., Stamatopoulos, L., Palyvos, N., Pucci, S., Lemeille, F. and Pavlides, S., 2004. Palaeoseismological investigations of the Aigion Fault (Gulf of Corinth, Greece), C. R. Geoscience, 336, 335-342.

Papadopoulos, G.A., 2011. A seismic history of Crete. The Hellenic Arc and Trench, Ocelotos publications, Athens.

Pavlides, S. and Caputo, R., 2004. Magnitude versus faults' surface parameters: Quantitative relationships from the Aegean Region, Tectonophysics, 380, 159-188.

Pavlides, S., Zhang, P. and Pantosti, D., 1999. Earthquakes, active faulting, and paleo - seismological studies for the reconstruction of seismic history of faults, Tectonophysics, 308 vii-x.

Pavlides, S., Koukouvelas, I., Kokkalas, S., Stamatopoulos, L., Keramydas, D. and Tsodoulos, I., 2004. Late Holocene evolution of the East Eliki fault, Gulf of Corinth (Central Greece), Quatern. Int., 115-116, 139-154.

Sakellarakis, Y., 1994. The temple of Anemospilia, Archaiologia, 53, 24-28 (in Greek).

Sakellarakis, Y., 1997. Excavating the past, Ammos publications, Athens (in Greek).

Solonenko, V.P., 1973. Palaeoseismogeology, Earth Physics, 9, Izv. AN. SSSR, 3-16.

Sieh, K.E., 1978. Prehistoric large earthquakes produced by slip on the San Andreas fault at Pallet Creek, California, J. Geophys. Res., 83, 3907-3939.

Vassilakis, E., 2006. Study of the tectonic structure of Messara Basin, Central Crete with the aid of remote sensing techniques and geographic information systems, $\mathrm{PhD}$ Thesis, Athens, (in Greek).

Wallace, R.E., 1981. Active faults, Paleoseismology, and earthquake hazards in the Western United States. Earthquake prediction: an international review, 209-216.

Zygouri, V., Koukouvelas, I., Kokkalas, S., Xypolias, P. and Papadopoulos, G.A., 2015. The Nisi Fault as a key structure for understanding the active deformation of the NW Peloponnese, Greece, Geomorphology, 237, 142-156. 